\title{
KORELASI DINAMIS PASAR SAHAM ASEAN DENGAN NILAI TUKAR DOLLAR AMERIKA SERIKAT (USD) DI ERA DONALD TRUMP
}

\author{
Yonatan Alvin Stefan ${ }^{1}$, Robiyanto ${ }^{2}$ \\ ${ }^{1,2}$ Fakultas Ekonomika dan Bisnis \\ Universitas Kristen Satya Wacana Salatiga \\ Indonesia
}

e-mail: 212016303@student.uksw.edu1, robiyanto@staff.uksw.edu²

\begin{abstract}
Abstrak
Pasca terpilihnya Donald Trump menjadi Presiden Amerika Serikat memberikan pengaruh terhadap perekonomian dunia dengan berbagai kebijakan yang ditetapkan, salah satunya memberi dampak pada pasar saham negara-negara ASEAN, oleh karena itu peneliti ingin mencari tahu korelasi dinamis antara nilai tukar USD dengan Pasar Saham ASEAN seperti di Indonesia, Malaysia, Singapura, Filipina, Thailand, dan Vietnam dengan menggunakan teknik analisis Dynamic Conditional CorrelationGeneralized Autoregressive Conditional Heteroscedasticity (DCC-GARCH), dikarenakan penelitian-penelitian terdahulu masih banyak menggunakan pendekatan statis. Penelitian ini menunjukkan bahwa korelasi antara nilai tukar USD dengan Pasar Saham ASEAN tidak statis, namun berubah secara dinamis sesuai dengan kondisi pasar yang terjadi. Dalam kondisi normal, nilai DCC-GARCH cenderung sangatlah lemah. Ditemukan juga korelasi dinamis negatif di pasar saham di negara Indonesia, Malaysia, Singapura, dan Thailand. Secara singkat dapat disimpulkan bahwa kebijakan yang diambil Donald Trump tidak memberi efek yang signifikan terhadap Pasar Saham ASEAN.
\end{abstract}

Kata kunci : Pasar Saham ASEAN: Nilai tukar USD: Dynamic Conditional Correlation-Generalized Autoregressive Conditional Heteroscedasticity (DCC-GARCH)

\begin{abstract}
After Donald Trump's election as President of the United States of America has an impact on the world economy with various policies determined, one of which has an impact on the stock markets of ASEAN countries, therefore researchers want to find out the dynamic correlation between the USD exchange rate with the ASEAN Stock Market as in Indonesia, Malaysia, Singapore, the Philippines, Thailand, and Vietnam using Dynamic Conditional Correlation-Generalized Autoregressive Conditional Heteroscedasticity (DCC-GARCH) analysis techniques, because many previous studies still use a static approach. This study shows that the correlation between the USD exchange rate with the ASEAN Stock Market is not static, but changes dynamically according to the prevailing market conditions. During the normal condition, the DCC-GARCH value tends to be very weak. Also found negative negative correlations on the stock markets in Indonesia, Malaysia, Singapore and Thailand. In short, it can be concluded that Donald Trump's policies have not a significant effect on the ASEAN Stock Market.
\end{abstract}

Keywords : ASEAN Stock Market: USD exchange rate: Dynamic Conditional Correlation-Generalized Autoregressive Conditional Heteroscedasticity (DCC-GARCH). 


\section{PENDAHULUAN}

Pada era globalisasi seperti saat ini, arus investasi semakin besar mengalir di pasar modal khususnya pada investasi saham. Kondisi tersebut terjadi, karena sejak sekitar akhir tahun 1980-an banyak negara berkembang memutuskan agar investor asing juga dapat berinvestasi ke pasar modal mereka, hal tersebut berdampak positif bagi infrastruktur kelembagaan dan pertumbuhan substansial yang diiringi dengan meningkatnya minat investor dalam berinvestasi di aset pasar negara berkembang (Nguyen \& Bellalah,
2008), oleh karena itu investor asing juga dapat berinvestasi di pasar modal khususnya pada investasi saham yang beberapa diantaranya di perusahaan-perusahaan negara berkembang di kawasan Asia Tenggara yang tergabung dalam Association of Southeast Asian Nations (ASEAN). Terbukti juga sudah banyak perusahaan-perusahaan yang tercatat di Pasar Saham ASEAN, khususnya di Indonesia, Malaysia, Singapura, Filipina, Thailand, dan Vietnam.

Tabel 1. Jumlah Perusahaan Tercatat di Enam Negara ASEAN

\begin{tabular}{cc}
\hline Negara & Jumlah Perusahaan Tercatat \\
\hline Indonesia & 629 \\
Malaysia & 927 \\
Singapura & 747 \\
Filipina & 322 \\
Thailand & 889 \\
Vietnam & 1335
\end{tabular}

Sumber : Alamat website resmi pasar saham negara masing-masing dan data diolah sendiri

Tabel 2. Nilai Kapitalisasi Pasar di Enam Negara ASEAN

\begin{tabular}{cc}
\hline Negara & $\begin{array}{c}\text { Kapitalisasi Pasar } \\
\text { (USD Milliar) }\end{array}$ \\
\hline Indonesia & 483,03 \\
Malaysia & 413,86 \\
Singapura & 555,13 \\
Filipina & 265,18 \\
Thailand & 459,67 \\
Vietnam & 113,90
\end{tabular}

Sumber : www.bloomberg.com

\begin{abstract}
Pada Tabel 1. dapat dilihat bahwa terdapat jumlah perusahaan-perusahaan tercatat di enam pasar saham ASEAN dapat menjadi referensi investor untuk berinvestasi di pasar saham, selain itu enam negara tersebut juga memiliki nilai kapitalisasi pasar yang terbesar di perhimpunan negara-negara di kawasan Asia Tenggara yang dapat dilihat pada Tabel 2., namun tentunya dalam berinvestasi tentu ada banyak risiko yang dapat mempengaruhi harga saham. Salah satu variabel yang dapat memiliki hubungan dengan harga saham adalah nilai tukar USD (Robiyanto, 2018b). Penelitian dari Rath (2017) menemukan bahwa ada hubungan antara nilai tukar dengan harga saham dengan
\end{abstract}

uji kausalitas granger pada Pasar Saham India, selain itu Gumilang, Hidayat, \& NP (2014) yang juga menemukan adanya hubungan nilai tukar USD pada Pasar Saham Indonesia, hal tersebut terjadi karena pada saat ini USD menjadi acuan bagi negaranegara di dunia untuk transaksi perdangangan internasional dan cadangan devisa primer (Pamungkas \& Darmawan, 2016) serta peran partisipasi investor dari Amerika Serikat yang menjadikan pasar negara berkembang menjadi efektif dan lebih besar (Nguyen \& Bellalah, 2008). maka peneliti menduga bahwa nilai tukar USD berkorelasi dengan Pasar Saham ASEAN pada kondisi pasar yang dinamis. 


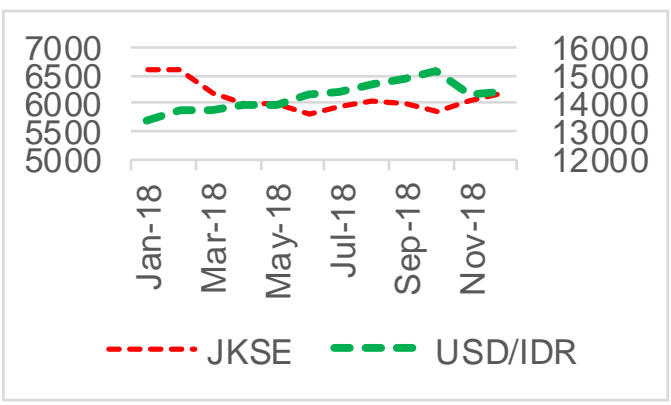

Sumber : www.investing.com

Gambar 1. Pergerakan JKSE dan USD/IDR Tahun 2018

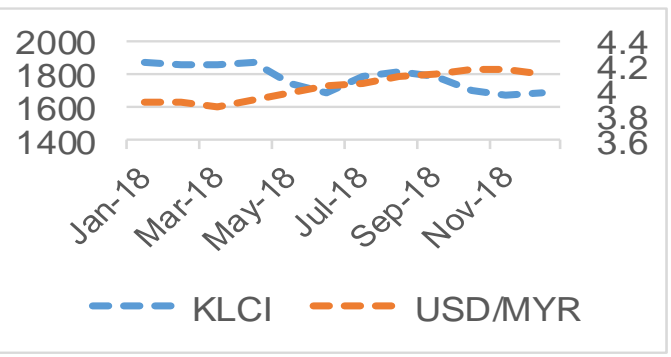

Sumber : www.investing.com

Gambar 2. Pergerakan KLCI dan USD/MYR Tahun 201

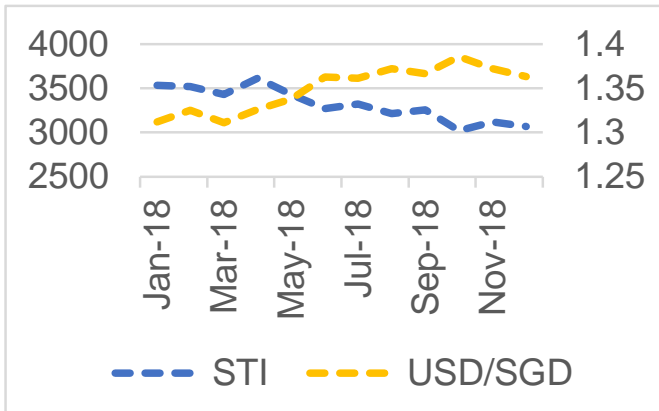

Sumber : www.investing.com

Gambar 3. Pergerakan STI dan USD/SGD Tahun 2018

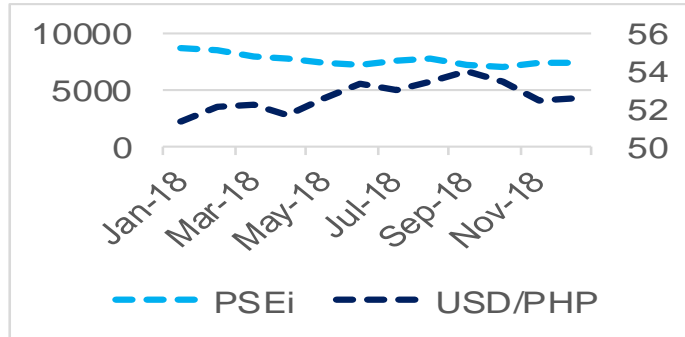

Sumber : www.investing.com

Gambar 4. Pergerakan PSEi dan USD/PHP Tahun 2018

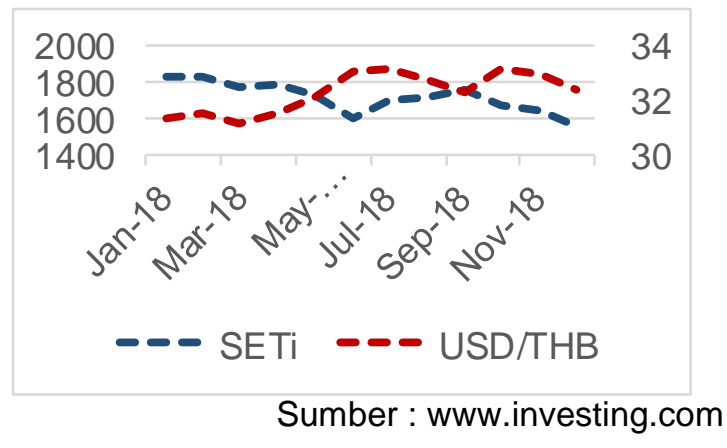

Gambar 5. Pergerakan SETi dan USD/THB Tahun 2018

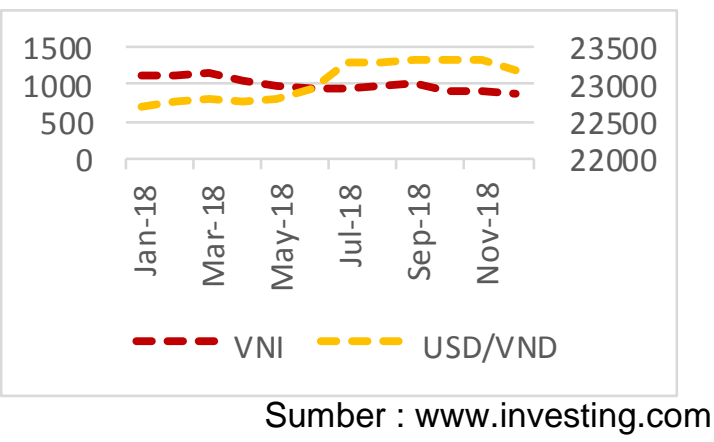

Gambar 6. Pergerakan VNI dan USD/VND Tahun 2018

Pada Gambar 1. hingga Gambar 6. dapat dilihat bahwa fenomena pergerakan indeks harga saham dan nilai tukar USD di sepanjang tahun 2018 bergerak secara dinamis, sesuai dengan kondisi pasar saham ASEAN yang cenderung cepat berubah sesuai kondisi yang ada (Robiyanto, 2018a). Penelitian mengenai korelasi dinamis antara nilai tukar dengan pasar saham pernah diteliti di beberapa negara Eropa Timur Zivkov (2016), kemudian Chen, Mantegna, Pantelous, \& Zuev (2018) juga pernah menguji korelasi dinamis nilai tukar dengan S\&P 500, FTSE 100 dan EURO STOXX 50, selain itu Robiyanto (2018a) juga pernah meneliti korelasi dinamis pada lima pasar saham di ASEAN dengan harga minyak dunia, dan Abolaji Daniel Anifowose (2017) juga pernah meneliti korelasi dinamis pada pasar uang Thailand dengan nilai tukar USD, maka dari itu peneliti ingin melakukan penelitian ini, karena sepanjang sepengetahuan peneliti, belum terdapat penelitian yang menguji korelasi dinamis pasar saham ASEAN dengan nilai tukar USD.

Berbagai kajian mengenai korelasi perubahan nilai tukar USD dengan pasar saham kebanyakan menggunakan pendekatan statis seperti penelitian dari Pamungkas \& 
Darmawan, (2016), Gumilang et al. (2014), Budialim (2013) dan Budiantara (2012) yang meneliti Indeks Harga Saham Gabungan (IHSG) dengan teknik analisis linier berganda, padahal kondisi pasar bergerak dinamis, selain itu Greenwood (2005) juga pernah meneliti namun menggunakan pendekatan berbeda, sebuah pendekatan yang dapat menguji ada tidaknya suatu hubungan jangka pendek ataupun jangka panjang, oleh karena itu penelitian ini menggunakan pendekatan yang berbeda yaitu Dynamic Conditional Correlation-Generalized Autoregressive Conditional Heteroscedasticity (DCC-GARCH) yang dapat berguna untuk melihat korelasi dinamis antar variabel yang ada di penelitian ini. karena DCC-GARCH telah terbukti dapat diestimasi secara berturut-turut untuk matriks kovarian yang bervariasi dalam jangka panjang (Filis, Degiannakis, \& Floros, 2011), meskipun ada beberapa teknik analisis lain yang dapat dipakai seperti Orthogonal-GARCH (Robiyanto, 2017).

Penelitian ini menggunakan periode waktu ketika Presiden Donald Trump dilantik, dikarenakan variabel bebas penelitian ini adalah nilai tukar USD yang merupakan mata uang negara adidaya yaitu Amerika Serikat, sehingga dapat mendominasi dan menjadi paramater menguat atau melemahnya nilai tukar mata uang suatu negara (Pamungkas \& Darmawan, 2016). Putra \& Putri (2018) juga berpendapat bahwa dengan terpilihnya Donald Trump dapat mempengaruhi kondisi perekonomian dunia dengan berbagai pembatalan perjanjian perdagangan yang dianggap merugikan Amerika Serikat (AS). Kebijakan yang dibuat dirasa anti terhadap globalisasi dan liberalisasi dikhawatirkan menimbulkan ketidakstabilan ekonomi dunia, salah satunya dikhawatirkan berimbas di Pasar Saham ASEAN. Terbukti adanya perubahan abnormal return pada Pasar Modal Indonesia khususnya pada indeks KOMPAS100 (Putra \& Putri, 2018) serta trading volume activity pada LQ 45 (Silaban \& Sedana, 2018), selain itu terjadinya integrasi lima pasar modal ASEAN yang menyebabkan mendapat efek penularan baik jangka panjang maupun jangka pendek pasca terpilihnya Trump menjadi presiden ke-45 AS di lima negara ASEAN yaitu Indonesia, Malaysia, Singapura, Thailand. Dan Filipina (Suganda \& Hariyono, 2018), oleh karena itu dapat dilihat bahwa hal tersebut menunjukkan peristiwa politik tersebut mengandung informasi penting yang dapat mempengaruhi investor dalam pengambilan keputusan investasi sehingga menimbulkan reaksi pasar saham di Era
Donald Trump, contohnya adanya market overreaction di Indeks LQ 45 (Sabina \& Sulasmiyati, 2017).

Berdasarkan uraian di atas dapat diambil suatu rumusan masalah yaitu "Bagaimana korelasi dinamis antara nilai tukar USD terhadap Pasar Saham ASEAN di Era Donald Trump?" Tujuan dari penelitian ini untuk mengetahui korelasi dinamis enam Pasar Saham di ASEAN dengan nilai tukar USD khususnya pada saat Donald Trump menjabat sebagai Presiden AS, sehingga ke depan dapat dijadikan sebagai referensi investor dalam negeri maupun luar negeri yang ingin berinvestasi saham di Indonesia, Malaysia, Singapura, Filipina, Thailand, dan Vietnam dengan fokus memperhatikan korelasi USD pada kondisi pasar yang dinamis, ketika kepemimpinan Amerika Serikat berada di tangan Donald Trump

\section{Capital Asset Pricing Model}

Pada penelitian ini menggunakan landasan teori Capital Asset Pricing Model (CAPM). Teori tersebut merupakan sebuah model yang pertama kali dikembangkan oleh tiga tokoh yaitu William F.Sharpe, Litner dan Mossin di tahun 1960 yang menghubungkan tingkat pengembalian yang diharapkan dari sebuah asset dengan risikonya pada kondisi pasar yang seimbang (Hendrawan, Sharpe, \& Weston, 2010). Sebagai sebuah model, CAPM dapat membantu menyederhankan korelasi return dan risiko pada dunia nyata yang terkadang sangat kompleks, sehingga para investor dapat meminimalisis risiko dan memperoleh tingkat pengembalian yang berlebih.

\section{METODE \\ Jenis dan Sumber Data}

Penelitian ini menggunakan sumber data sekunder yang diambil dari www.investing.com untuk data harian dari indeks harga saham di enam Pasar Saham ASEAN yaitu Jakarta Stock Exchange Composite Index (JKSE), Kuala Lumpur Composite Index (KLCl), Straits Times Index (STI), Philippine Stock Exchange Index (PSEi), Stock Exchange of Thailand Index (SETi), serta Vietnam Ho Chi Minh Stock Index (VNI) dan nilai tukar USD dari Indonesia, Malaysia, Singapura, Filipina, Thailand, dan Vietnam dimulai dari tanggal dilantiknya Donald Trump yaitu 20 Januari 2017 hingga 21 Juni 2019. 


\section{Populasi dan Sample}

Populasi pada penelitian ini adalah sebelas negara yang tergabung dalam ASEAN, namun menggunakan metode pengambilan sample yaitu purposive sampling method dengan kriteria dipilih negara ASEAN yang memiliki kapitalisasi pasar terbesar dan sudah aktif, maka ditentukanlah terdapat enam negara yang menjadi sample pada penelitian ini, yaitu Indonesia, Malaysia, Singapura, Filipina, Thailand, dan Vietnam.

\section{Definisi Operasional Variabel}

Pada penelitian ini yang menjadi variable terikat adalah return saham dari enam Pasar Saham ASEAN dan variabel bebasnya adalah perubahan nilai tukar USD dari enam negara ASEAN yang dihitung dari setiap data minggunya, yang dihitung dengan rumus sebagai berikut : saham :

Rumus untuk mencari return dari pasar

$$
R t=\frac{I(t)-I(t-1)}{I(t-1)}
$$

Rumus untuk mencari perubahan nilai tukar USD :

$$
\triangle E R=\frac{E R(t)-E R(t-1)}{E R(t-1)}
$$

Keterangan :

$\mathrm{Rt}=$ return saham

$I(t)=$ Indeks harga saham hari ini

$\mathrm{I}(\mathrm{t}-1)=$ Indeks harga saham hari sebelumnya

$\triangle \mathrm{ER}=$ Perubahan nilai tukar USD

$\mathrm{ER}(\mathrm{t})=$ Nilai tukar USD hari ini

$\mathrm{ER}(\mathrm{t}-1)=$ Nilai tukar USD hari sebelumnya

\section{Teknik Analisis}

$$
\text { Metode }
$$

Dynamic

Conditional

Correlation-Generalized Autoregressive Conditional Heteroscedasticity (DCC-GARCH) pertama kali diperkenalkan oleh (Engle, 2002) dengan spesifikasi seperti berikut ini :

$$
\mathrm{rt} \mid=\mathrm{t}-1 \sim \mathrm{N}(0, \mathrm{Dt} \mathrm{Rt} \mathrm{Dt})
$$

$D t 2=\operatorname{diag}\{\omega i\}+\operatorname{diag}\{\kappa i\}^{\circ} \mathrm{rt}-1 r t-1^{\prime}+\operatorname{diag}\{\lambda i\}$ ${ }^{\circ} D t-12$

$$
\varepsilon \mathrm{t}=D t-1 \mathrm{rt}
$$

$Q t=S^{\circ}\left(I I^{\prime}-A-B\right)+A^{\circ} \varepsilon t-1 \varepsilon t-1^{\prime}+B^{\circ} Q t-1$

$\mathrm{Rt}=\operatorname{diag}\{Q i\}-1 Q t \operatorname{diag}\{Q i\}-$

Untuk logaritma penaksir atau Log Likehood adalah sebagai berikut :

$$
\mathrm{rt} \mid=\mathrm{t}-1 \sim \mathrm{N}(0, \mathrm{Ht})
$$

$$
\mathrm{L}=\frac{\left.-12 \sum^{\prime} H t-1 r t\right)}{(n \log (2 \pi)+\log |H t| T t=1+r t}
$$

$=-12 \sum(n \log (2 \pi)+\log |D t R t D t| T t$

$\left.=1+r t t^{\prime} D t-1 R t-1 D t-1 r t\right)=-12 \sum(n \log (2 \pi)+$ $2 \log |D t| T t$

$\left.=1+\log |R t|+\varepsilon t{ }^{\prime} R t-1 \varepsilon t\right)=-12 \sum(n \log (2 \pi)+$ $2 \log |D t| T t$

$=1+r t \quad D t-1 D t-1 r t-\varepsilon t \quad ' \varepsilon t+\log |R t|+\varepsilon t$ 'Rt-1عt),

Model tersebut dapat dimaksimalkan dalam parameter model, salah satu tujuannya adalah untuk memudahkan suatu prediksi melalui matriks co-varian yang sangat besar Newey \& McFadden (1994) menjelaskan bahwa perumusan model dilakukan ke dalam konsistensi dan normalitas asimptotik dari parameter yang memenuhi syarat, jika parameter $D$ dicatat dengan $\phi$ dan parameter tambahan dalam $\mathrm{R}$ dicatat dengan $\theta$, Loglikelihood dapat dinyatakan sebagai jumlah volatilitas parsial dan korelasi sebagai berikut $\mathrm{L}(\theta, \phi)=\mathrm{LV}(\theta)+\mathrm{LC}(\theta, \phi)$ berikut :

Rumus dari volalitas adalah sebagai $(\theta)=-1 / 2 \sum\left(n \log (2 \pi)+\log \left|D_{t}\right|^{2}+r_{t}{ }^{\prime} D_{t}{ }^{-2} r_{t}\right)$ berikut :

Komponen dari korelasi adalah sebagai $(\theta, \phi)=-1 / 2 \sum\left(\log \left|R_{t}\right|+\varepsilon_{t}{ }^{\prime} R_{t}{ }^{-1} \varepsilon_{t}-\varepsilon_{t}{ }^{\prime} \varepsilon_{t}\right)$

Partital volalitas adalah jumlah dari GARCH likehood tiap individu : $L V(\theta)=-1 / 2 \sum_{t} \sum_{i=0}^{n}\left(\log (2 \pi)+\log (h i, t)+r_{i, t} / h\right.$ $i, t))$

Jika digabungkan dapat dimaksimalkan dengan mengoptimalkan setiap istilah. Bagian kedua dari kemungkinan dilakukan untuk memperkirakan parameter korelasi. Mempertimbangkan residu kuadrat ini tidak terikat dengan parameter ini, sehingga hal-hal itu tidak dapat terlibat dalam kondisi urutan pertama dan harus diabaikan. Estimator yang dihasilkan kemudian disebut DCC LL INT, karena menggunakan model terintegrasi. Pendekatan dua langkah untuk mengoptimalkan kemungkinan digunakan untuk menghasilkan

$\theta=\arg \max (L V(\theta)) \mid$

Nilai tersebut melangkah pada step ke dua: $\max \{\phi L C(\theta, \phi)\}$

Model DCC-GARCH juga telah digunakan oleh (Robiyanto, Sugeng, Pangestuti, \& Demi 
(2017) dalam mempelajari hubungan dinamis antara pasar saham Indonesia dan pasar saham Malaysia dengan harga emas, sedangkan variasi model GARCH seperti OGARCH (Orthogonal Generalized Autoregressive Conditional Heteroscedasticity) juga telah digunakan oleh (Robiyanto, 2017). Penelitian ini tidak menggunakan panel
GARCH yang diusulkan oleh Cermeño \& Grier (2001), karena penelitian ini mencoba menguji korelasi yang bervariasi waktu untuk seri waktu tunggal untuk setiap pasar saham yang diteliti.

\section{HASIL DAN PEMBAHASAN}

Tabel 2. Hasil Uji Augmented Dicky-Fuller pada Return (First Difference)

\begin{tabular}{ll}
\hline Variabel & Statistik Augmented Dicky-Fuller \\
\hline JKSE & $-16.78603^{*}$ \\
KLCI & $-16.65580^{*}$ \\
STI & $-15.96896^{*}$ \\
PSEi & $-13.86363^{*}$ \\
SETi & $-15.18663^{*}$ \\
VNI & $-14.56367^{*}$ \\
USD_IDR & $-14.68083^{*}$ \\
USD_MYR & $-15.75311^{*}$ \\
USD_SGD & $-18.54755^{*}$ \\
USD_PHP & $-15.30081^{*}$ \\
USD_THB & $-18.08583^{*}$ \\
USD_VND & $-17.77474^{*}$ \\
\hline
\end{tabular}

Catatan : ${ }^{*}$ tingkat signifikansi statistik sebesar $1 \%$

Pengujian data stasioner dilakukan dengan uji Augmented Dickey-Fuller (ADF) yang dapat dilihat pada Tabel 3. Dengan melihat tabel tersebut dapat diambil kesimpulan bahwa semua nilai statistik Augmented Dicky-Fuller (First Difference), semua variabel pada penelitian ini signifikan pada tingkat signifikansi 1 persen yang menunjukkan bahwa semua data yang digunakan adalah data stasioner

Korelasi Dinamis Nilai Tukar USD dengan Pasar Saham ASEAN dengan Variasi Waktu

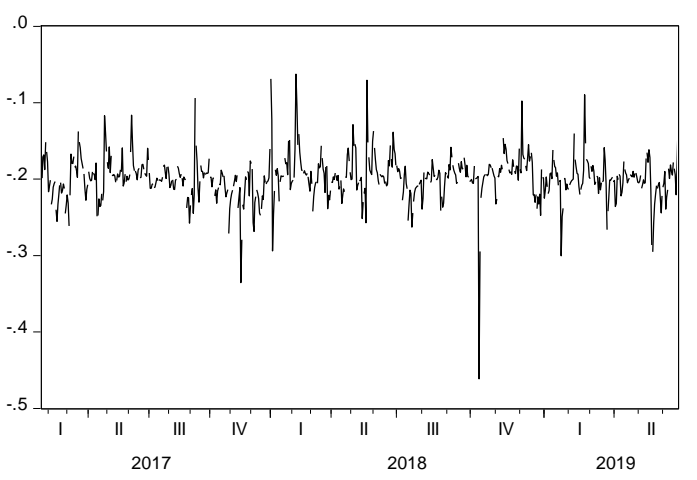

Gambar 7. Korelasi Dinamis JKSE-USD/IDR

Tabel 3. Peristiwa Penting di Indonesia

\begin{tabular}{lc}
\hline \multicolumn{1}{c}{ Peristiwa } & Waktu \\
\hline $\begin{array}{l}\text { Serentetan pengeboman di kota kedua Surabaya, } \\
\text { dilakukan oleh keluarga pelaku bom bunuh diri, termasuk } \\
\text { anak-anak mereka. }\end{array}$ & Mei 2018 \\
$\begin{array}{l}\text { Gempa bumi dan tsunami besar menewaskan lebih dari } \\
1.000 \text { orang di pulau Sulawesi, di sekitar kota Palu. }\end{array}$ & September 2018 \\
\hline
\end{tabular}


Pesawat Boeing 737 Max 8 baru yang dioperasikan oleh

Oktober 2018

Lion Air Indonesia menabrak Laut Jawa, menewaskan

189 orang di dalamnya. Kecelakaan serupa di Ethiopia pada Maret berikutnya menyebabkan landasan 737 Max 8 di seluruh dunia menunggu investigasi.

Pemilihan presiden dan legislatif diadakan secara bersamaan untuk pertama kalinya. Lebih dari 192 juta warga mendaftar untuk memilih presiden dan legislator untuk 20.500 kursi dalam latihan raksasa.

Sumber : BBC (2019)

Pada Gambar 7. dapat dilihat hasil analisis dengan menggunakan DCC-GARCH, hasilnya menunjukkan bahwa nilai DCC antara nilai tukar USD/IDR dengan Jakarta Stock Exchange Composite Index (JKSE) selama periode penelitian berada pada kisaran -0.088 hingga 0.034. Nilai terendah terjadi di pertengahan tahun 2018, sedangkan nilai tertinggi terjadi pada akhir tahun 2018. Pada Tabel 11. juga dapat dilihat bahwa rata-rata nilai DCC sebesar -0.001. Ini menunjukkan bahwa korelasi dinamis antara nilai tukar USD dengan Pasar Saham Indonesia di era Donald Trump adalah negatif dan masih sangatlah lemah. Beberapa peristiswa penting di Indonesia yang dapat dilihat di Tabel 4. juga tidak memberikan efek terhadap korelasi dinamis antara nilai tukar USD dengan Pasar Saham Indonesia.

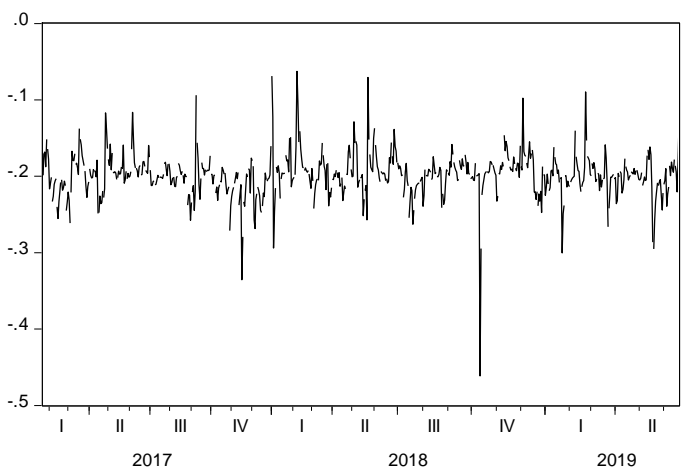

Gambar 8. Korelasi Dinamis KLCI-USD/MYR

Tabel 4. Peristiwa Penting di Malaysia

\section{Peristiwa}

Kim Jong-nam, saudara lelaki terasing pemimpin Korea Utara

Kim Jong-un, terbunuh dengan agen saraf di bandara

Malaysia.

Mahathir Mohamad kembali menjadi perdana menteri sebagai kepala koalisi empat partai, mengalahkan anak didiknya, Najib

Razak.

\section{Waktu}

Februari 2017

Mei 2018

Sumber : BBC (2019b)

Pada Gambar 8 menunjukkan hasil analisis dengan menggunakan DCC-GARCH, hasilnya menunjukkan bahwa nilai DCC antara nilai tukar USD/MYR dengan Kuala Lumpur Composite Index $(\mathrm{KLCl})$ selama periode penelitian berada pada kisaran -0.461 hingga 0.063. Nilai terendah terjadi di bulan November 2018, sedangkan nilai tertinggi terjadi pada bulan Februari 2018. Rata-rata nilai DCC dapat dilihat pada Tabel 11. yang menunjukkan nilai sebesar -0.199. Besarnya nilai tersebut menunjukkan bahwa korelasi dinamis antara nilai tukar USD dengan Pasar Saham Malaysia di era Donald Trump negatif dan masih sangatlah rendah, selain itu peristiwa-peristiwa penting yang terjadi di Malaysia yang dapat dilihat di Tabel 5. juga tidak memberikan efek terhadap korelasi dinamis antara nilai tukar USD dengan Pasar Saham Malaysia.

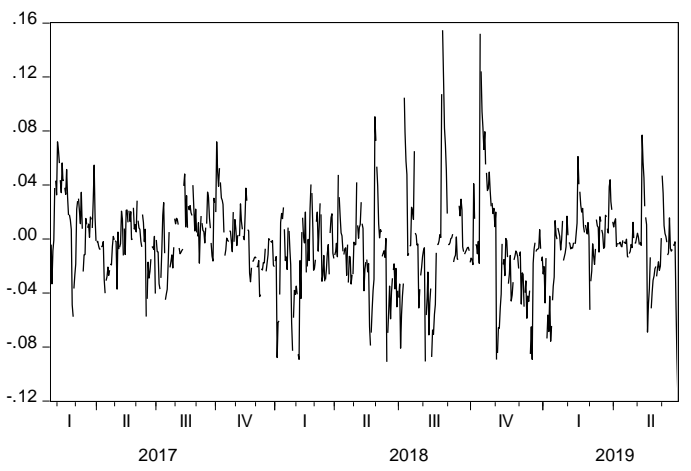

Gambar 9. Korelasi Dinamis STI-USD/SGD 
Tabel 5. Peristiwa Penting di Singapura

\begin{tabular}{lc}
\hline Peristiwa & Waktu \\
\hline $\begin{array}{l}\text { Seorang blogger remaja diberikan suaka di AS. Seorang hakim } \\
\text { mengatakan Amos Yee telah dianiaya karena pendapat }\end{array}$ & Maret 2017 \\
politiknya. & \\
Perdana Menteri Lee Hsien Loong dan saudara-saudaranya & Juli 2017 \\
terlibat dalam perselisihan publik atas kehendak mendiang ayah & \\
mereka, mantan perdana menteri Lee Kuan Yew. & April 2019 \\
Pemilihan presiden dan legislatif diadakan secara bersamaan & \\
untuk pertama kalinya. Lebih dari 192 juta warga mendaftar \\
untuk memilih presiden dan legislator untuk 20.500 kursi dalam \\
latihan raksasa.
\end{tabular}

Hasil analisis dengan menggunakan DCC-GARCH, hasilnya menunjukkan bahwa nilai DCC antara nilai tukar USD/SGD dengan Straits Times Index (STI) selama periode penelitian berada pada kisaran -0.117 hingga 0.115 dapat dilihat di Gambar 9. Nilai terendah terjadi di pertengah tahun 2019 yang merupalan akhir dari periode penelitian, sedangkan nilai tertinggi terjadi pada bulan Agustus 2018 dan rata-rata nilai DCC yang dapat dilihat di Tabel 11. adalah sebesar 0.004 . Hal tersebut menunjukkan bahwa korelasi dinamis antara nilai tukar USD dengan Pasar Saham Singapura di era Donald Trump adalah negatif dan masih sangatlah terlalu lemah, selain itu peristiwa-peristiwa penting yang terjadi di Singapura yang dapat dilihat di Tabel 6. juga tidak memberikan efek terhadap korelasi dinamis antara nilai tukar USD dengan Pasar Saham Singapura.

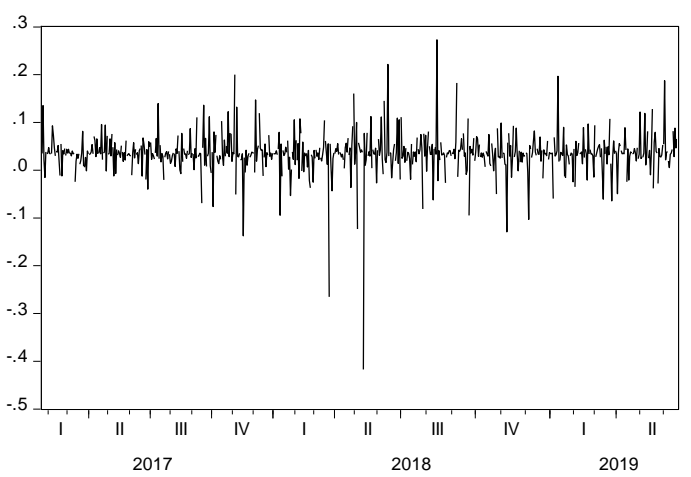

Gambar 10. Korelasi Dinamis PSEi-USD/PHP

Tabel 6. Peristiwa Penting di Filipina

\begin{tabular}{lc}
\hline \multicolumn{1}{c}{ Peristiwa } & Waktu \\
\hline Hukum darurat diberlakukan di pulau Mindanao setelah & Mei 2017 \\
pertempuran meletus antara pasukan keamanan dan militan \\
yang terkait dengan Negara Islam dari kelompok Maute dan \\
Isnilon Hapilon. \\
$\begin{array}{l}\text { Kota selatan Marawai dinyatakan dibebaskan dari para pejuang } \\
\text { jihadis yang menahannya selama hampir lima bulan }\end{array}$ \\
\hline
\end{tabular}

Sumber : BBC (2019c)

Gambar 10. menunjukkan hasil analisis dengan menggunakan DCC-GARCH, hasilnya menunjukkan bahwa nilai DCC antara nilai tukar USD/PHP dengan Philippine Stock Exchange Index (PSEi) selama periode penelitian berada pada kisaran -0.417 hingga 0.273 dengan rata-rata nilai sebesar 0.035 yang dapat dilihat pada Tabel 11. Nilai terendah terjadi di bulan Mei 2018, sedangkan nilai tertinggi terjadi pada bulan Agustus 2018. Rata-rata nilai tersebut menunjukkan bahwa korelasi dinamis antara nilai tukar USD dengan Pasar Saham Filipina di era Donald Trump masih sangatlah lemah, namun berkorelasi positif. Tabel 7. menunjukkan peristiwaperistiwa penting yang terjadi di Filipina yang juga tidak memiliki efek pada korelasi dinamis antara nilai tukar USD dengan Pasar Saham Filipina. 


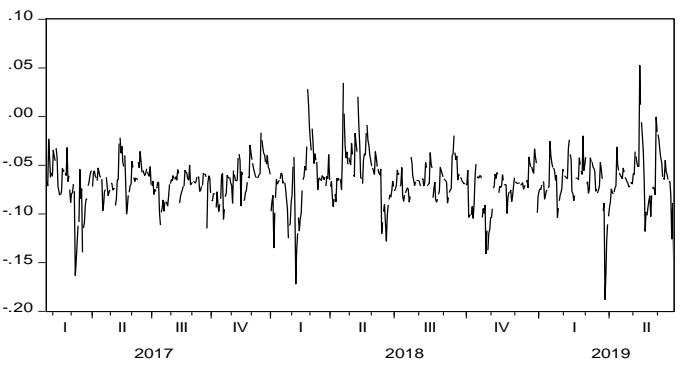

Gambar 11. Korelasi Dinamis SETi-USD/THB

Tabel 7 . Peristiwa Penting di Thailand

\begin{tabular}{|c|c|}
\hline Peristiwa & Waktu \\
\hline $\begin{array}{l}\text { Raja Vajiralongkorn menandatangani konstitusi baru yang } \\
\text { dirancang militer yang membuka jalan untuk kembali ke } \\
\text { demokrasi. }\end{array}$ & April 2017 \\
\hline Pemerintah menetapkan tanggal pemilihan umum untuk 24 Maret & Januari 2019 \\
\hline
\end{tabular}

Pada Gambar 11. yang menunjukkan hasil analisis dengan menggunakan DCC$\mathrm{GARCH}$, hasilnya menunjukkan bahwa nilai DCC antara nilai tukar USD/THB dengan Stock Exchange of Thailand Index (SETi) selama periode penelitian berada pada kisaran -0.188 hingga 0.053 . Nilai terendah terjadi di bulan Maret 2019, sedangkan nilai tertinggi terjadi pada bulan Mei 2019. Tabel 11. menunjukkan bahwa rata-rata nilai DCC sebesar -0.067. Ini menunjukkan bahwa korelasi dinamis antara nilai tukar USD dengan Pasar Saham Thailand di era Donald Trump adalah sangatlah lemah serta negatif. Peristiwa-peristiwa penting yang terjadi selama periode penelitian yang dapat dilihat pada Tabel 8. juga tidak memberikan efek pada korelasi dinamis nilai tukar USD dengan Pasar Saham Thailand.

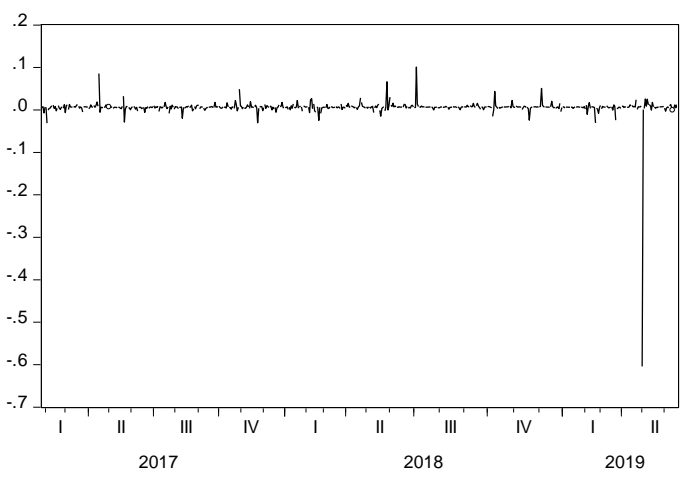

Gambar 12. Korelasi Dinamis VNI-USD/VND

Tabel 8. Peristiwa Penting di Vietnam

\begin{tabular}{lc}
\hline \multicolumn{1}{c}{ Peristiwa } & Waktu \\
\hline Vietnam memperkenalkan rancangan undang-undang yang & Januari 2017 \\
mewajibkan semua warga negara dewasa untuk menyumbangkan & \\
darah sebulan sekali karena kekurangan di bank darah nasional & \\
\hline
\end{tabular}

Pada Gambar 12. yang menunjukkan hasil analisis dengan menggunakan DCC$\mathrm{GARCH}$, hasilnya menunjukkan bahwa nilai DCC antara nilai tukar USD/VND dengan Vietnam Ho Chi Minh Stock Index (VNI) selama periode penelitian berada pada kisaran -0.604 hingga 0.101 . Nilai terendah terjadi di bulan Februari 2019, sedangkan nilai tertinggi terjadi pada bulan April 2018. Tabel 11. menunjukkan bahwa memiliki rata-rata nilai Tabel 10. Peristiwa Penting di Amerika Serikat sebesar 0.006 yang menunjukkan bahwa korelasi dinamis antara nilai tukar USD dengan Pasar Saham Vietnam di era Donald Trump sangatlah lemah dan positif. Sama dengan negara-negara lainnya satu peristiwa penting yang terjadi di Vietnam yang dapat dilihat di Tabel 9. juga tidak memberikan efek pada korelasi dinamis nilai tukar USD dengan Pasar Saham Vietnam. 


\begin{tabular}{|c|c|}
\hline $\begin{array}{c}\text { Peristiwa } \\
\text { Prociden Trumn memecat Diroktur FRI lamec } \text { (nmey }\end{array}$ & Waktu \\
\hline $\begin{array}{l}\text { Presiden Trump memecat Direktur FBI James Comey, } \\
\text { mendorong pertikaian publik tentang apakah Gedung Putih } \\
\text { mencoba menggagalkan penyelidikan atas dugaan kolusi } \\
\text { antara upaya Rusia untuk mempengaruhi pemilu } 2016 \text { dan } \\
\text { kampanye Trump }\end{array}$ & Mei 2017 \\
\hline $\begin{array}{l}\text { Seorang wanita ditabrak dan dibunuh oleh tersangka } \\
\text { simpatisan sayap kanan di tengah-tengah protes di } \\
\text { Charlottesville, Virginia. Presiden Trump secara luas dikritik } \\
\text { karena menyalahkan kedua belah pihak atas kekerasan, } \\
\text { daripada kaum neo-Nazi dan supremasi kulit putih. }\end{array}$ & Agustus 2017 \\
\hline $\begin{array}{l}\text { AS mengakui Yerusalem sebagai ibu kota Israel dan } \\
\text { mengumumkan rencana untuk memindahkan kedutaan di } \\
\text { sana, memicu kemarahan di negara-negara Arab. }\end{array}$ & Desember 2017 \\
\hline $\begin{array}{l}\text { China mengenakan tarif } 25 \% \text { pada sejumlah barang AS } \\
\text { sebagai respons terhadap tindakan AS yang serupa. }\end{array}$ & April 2018 \\
\hline $\begin{array}{l}\text { Setelah berbulan-bulan retorika bermusuhan, Presiden Trump } \\
\text { dan pemimpin Korea Utara Kim Jong-un bertemu di } \\
\text { Singapura dan setuju untuk melanjutkan dialog yang } \\
\text { bertujuan mengurangi ketegangan di semenanjung Korea. }\end{array}$ & Juni 2018 \\
\hline $\begin{array}{l}\text { AS, Kanada dan Meksiko mencapai kesepakatan } \\
\text { perdagangan baru untuk menggantikan Perjanjian } \\
\text { Perdagangan Bebas Amerika Utara (Nafta) saat ini. }\end{array}$ & Oktober 2018 \\
\hline $\begin{array}{l}\text { Oposisi Demokrat mengambil kendali DPR dalam pemilihan } \\
\text { jangka menengah, membuatnya lebih sulit bagi Presiden } \\
\text { Republik Trump untuk mengesahkan undang-undang. }\end{array}$ & November 2018 \\
\hline $\begin{array}{l}\text { Menteri Pertahanan James Mattis mengundurkan diri setelah } \\
\text { Presiden Trump mengumumkan rencana untuk menarik } \\
\text { pasukan AS dari Suriah. }\end{array}$ & Desember 2018 \\
\hline $\begin{array}{l}\text { Pembicaraan AS dan Korea Utara di Vietnam gagal karena } \\
\text { laju pelucutan nuklir }\end{array}$ & Februari 2019 \\
\hline $\begin{array}{l}\text { Laporan Mueller tidak menemukan bukti kolusi antara upaya } \\
\text { Rusia untuk mempengaruhi pemilu } 2016 \text { dan kampanye } \\
\text { Trump. }\end{array}$ & Mei 2019 \\
\hline
\end{tabular}

Tabel 11. Korelasi Dinamis antara USD dan Pasar Saham ASEAN dengan Vareasi Waktu

\begin{tabular}{lccc}
\hline & Rata-rata & Max & Min \\
\hline JKSE-USD/IDR & -0.001 & 0.034 & -0.088 \\
KLCI-USD/MYR & -0.199 & -0.063 & -0.461 \\
STI-USD/SGD & -0.004 & 0.155 & -0.117 \\
PSEi-USD/PHP & 0.035 & 0.273 & -0.417 \\
SETi-USD/THB & -0.067 & 0.053 & -0.188 \\
VNI-USD/VND & 0.006 & 0.101 & -0.604 \\
\hline
\end{tabular}

Sumber : BBC (2019)

Beberapa peristiwa penting yang terjadi di Amerika serikat yang dapat dilihat di Tabel 10. tidak memberikan efek terhadap korelasi dinamis nilai tukar USD dengan Pasar Saham ASEAN. Kondisi tersebut terjadi karena peristiwa-peristiwa penting yang terjadi tidak ada yang berhubungan langsung dengan negara-negara yang tergabung dalam komunitas ASEAN. Hal tersebut berbeda dengan penelitian dari Robiyanto (2018a) yang menyatakan bahwa beberapa peristiwa penting di Amerika Serikat memberikan efek pada lima Pasar Saham ASEAN. Penelitian dari Filis et al. (2011) di negara-negara seperti Kanada, Meksiko, Brazil, Amerika Serikat, Jerman, dan Belanda juga ditemukan adanya pengaruh dari peristiwa-peristiwa penting yang terjadi, namun dua penelitian tersebut menggunakan variabel bebas yang berbeda yaitu harga minyak dunia.

Kondisi korelasi dinamis antara nilai tukar USD dengan Pasar Saham ASEAN 
mencerminkan suatu kondisi yang berbedabeda yang dapat dilihat di Tabel 11, namun secara keseluruhan korelasinya dapat dikatakan berhubungan sangat lemah. Pasar saham yang memiliki korelasi yang paling tinggi adalah milik negara Malaysia yaitu sebesar -0.199 dan yang paling rendah adalah Pasar Saham Indonesia yaitu sebesar -0.001 . Kondisi tersebut sejalan dengan peneltian yang menggunakan pendekatan statis dari Yusniar \& Sufi Jikrillah (2018) yang menemukan bahwa tidak adanya perbedaan signifikan pada pasar modal dan pasar uang dunia pada saat terpilinnya Donald Trump sebagai Presiden Amerika Serikat, selain itu negara-negara yang memiliki korelasi dinamis negatif di Pasar Saham ASEAN adalah Indonesia, Malaysia, Singapura, dan Thailand. Hal tersebut sejalan dengan penelitian korelasi dinamis nilai tukar USD dengan beberapa negara Eropa Timur (Zivkov, 2016) dan Chen et al. (2018) pada indeks S\&P 500, FTSE 100 dan EURO STOXX 50 yang sama-sama menggunakan pendekatan dinamis dan menemukan adanya korelasi dinamis negatif juga. Khusus untuk korelasi dinamis negatif nilai tukar USD dengan Pasar Saham Singapura juga sejalan dengan hasil penelitian dari (Pamungkas \& Darmawan, 2016) yang meneliti menggunakan pendekatan statis.

\section{PENUTUP}

Studi ini meneliti korelasi yang bervariasi waktu antara nilai tukar USD dengan Pasar Saham ASEAN di era Donald Trump dengan menggunakan DCC-GARCH yang ditemukan oleh Engle (2002). Teknik analisis tersebut memiliki kegunaan untuk memperkirakan korelasi bersyarat. Temuan ini memberikan bukti bahwa korelasi waktu yang bervariasi antara nilai tukar USD dan Pasar Saham ASEAN memiliki perbedaan untuk setiap negara. Dalam kondisi normal, nilai DCC-GARCH cenderung sangatlah lemah. Ditemukan juga korelasi dinamis negatif di pasar saham di negara Indonesia, Malaysia, Singapura, dan Thailand. Hasil penelitian ini sejalan dengan penelitian dari (Zivkov, 2016) dan (Chen et al., 2018). Korelasi dinamis yang sangat lemah antara nilai tukar USD dengan Pasar Saham ASEAN di Era Donald Trump menunjukkan bahwa kebijakan yang diambil Donald Trump tidak memberi efek yang signifikan terhadap Pasar Saham ASEAN, faktor-faktor internal di negara-negara tersebut bisa saja lebih memberikan efek daripada faktor eskternal seperti nilai tukar USD dan kebijakan politik yang dilakukan Donald Trump, selain itu korelasi yang sangatlah lemah tersebut disebabkan tidak adanya perang dagang secara langsung antara Amerika Serikat dengan negara-negara ASEAN, berbeda dengan perang dagan antara Amerika Serikat dengan China. Korelasi dinamis yang negatif di Indonesia, Malaysia, Singapura, dan Thailand juga menunjukkan hubungan yang berlawan arah antara nilai tukar USD dengan pasar saham ni negara tersebut yang hasilnya beberapa diantaranya sama dengan hasil penelitian dari (Pamungkas \& Darmawan, 2016).

Penelitian ini hanya menggunakan model bivariat, sehingga tidak dapat menangkap variabel eksogen. Penelitian lebih lanjut dapat menggunakan model multivariat yang akan dapat menjelaskan pengaruh variabel eksogen lainnya seperti variabel ekonomi makro atau variabel lain yang ada di internal negara tersebut, seperti suku bunga, pertumbuhan ekonomi, dan lain-lain. Panel dinamis GARCH dikombinasikan dengan DCC juga menyarankan penggunaan dalam penelitian lebih lanjut untuk menggeneralisasi temuan di negara-negara yang tergabung dalam komunitas ASEAN.

Bagi para investor asing maupun domestik di pasar saham yang ingin menginvestasikan uangnya di Pasar Saham ASEAN, berdasarkan hasil penelitian ini dapat memberi referesi bagi para investor untuk tidak perlu berfokus memperhatikan variabel nilai tukar USD terutama ketika Donald Trump memimpin, dikarenakan variabel bebas tersebut serta peristiwa-peristiwa politik terutama yang mencakup kebijakan Donald Trump hanya memiliki hubungan yang sangat lemah dengan Pasar Saham ASEAN, jadi investor tetap dapat direkomendasikan untuk berinvestasi ke Pasar Saham ASEAN, ketika nilai tukar USD dengan tiap-tiap negara ASEAN sedang buruk serta saat Donald Trump tetap menjadi Presiden Amerika Serikat.

\section{DAFTAR PUSTAKA}

BBC. (2019a). Indonesian Profile - Timeline. Retrieved August 26, 2019, from https://www.bbc.com/news/world-asiapacific-15114517

BBC. (2019b). Malaysian Profile - Timeline. Retrieved August 28, 2019, from https://www.bbc.com/news/world-asiapacific-15356257

BBC. (2019c). Philipines Profile - Timeline. Retrieved August 28, 2019, from 
https://www.bbc.com/news/world-asia15581450

BBC. (2019d). Singapore Profile - Timeline. Retrieved August 28, 2019, from https://www.bbc.com/news/world-asia15971013

BBC. (2019e). Thailand Profile - Timeline. Retrieved August 28, 2019, from https://www.bbc.com/news/world-asia15641745

BBC. (2019f). United States Profile - Timeline. Retrieved August 29, 2019, from https://www.bbc.com/news/world-uscanada-16759233

BBC. (2019g). Vietnam Profile - Timeline. Retrieved August 28, 2019, from https://www.bbc.com/news/world-asiapacific-16568035

Cermeño, R., \& Grier, K. B. (2001). Modeling GARCH processes in Panel Data: Theory, Simulations and Examples. The University of Oklahoma.

Chen, Y., Mantegna, R. N., Pantelous, A. A., \& Zuev, M. (2018). A dynamic analysis of $S$ \& P 500 , FTSE 100 and EURO STOXX 50 indices under different exchange rates.

Engle, R. (2002). Dynamic Conditional Correlation Dynamic Conditional Correlation: A Simple Class of Multivariate Generalized Autoregressive Conditional Heteroskedasticity Models. Journal of Business \& Economic Statistics, 20(3), 339-350. https://doi.org/10.1198/073500102288618 487

Filis, G., Degiannakis, S., \& Floros, C. (2011). International Review of Financial Analysis Dynamic correlation between stock market and oil prices: The case of oilimporting and oil-exporting countries. International Review of Financial Analysis, 20(3), 152-164. https://doi.org/10.1016/j.irfa.2011.02.014

Gumilang, R. C., Hidayat, R. R., \& NP, M. G. W. E. (2014). Pengaruh Variabel Makro Ekonomi, Harga Emas dan Harga MInyak dunia Terhadap Indeks Harga Saham Gabungan (Studi pada Bursa Efek Indonesia Periode 2009-2013). Jurnal Administrasi Bisnis (JAB), 14(2), 1-9.
Hendrawan, B., Sharpe, W. F., \& Weston, M. (2010). Pengujian Capital Asset Pricing Model ( CAPM ) secara Empiris terhadap Kelompok Saham Kompas 100 ( K-100 ). Jurnal Integrasi, 2(1), 10-17.

http://www.bursamalaysia.com/market/listedcompanies/companyannouncements/6097193. Diakses pada tanggal 15 Mei 2019

https://www.hsx.vn/Modules/Listed/Web/Listing Summary $/ 153$ ?fid=8761a1187cea4f3383 9ffa5a936e62c1. Diakses pada tanggal 15 Mei 2019

https://www.idx.co.id/perusahaantercatat/profil-perusahaan-tercatat/. Retrieved May 15, 2019

https://investasi.kontan.co.id/news/market-capindonesia-di-urutan-kedua-asean. Retrieved May 21, 2019

https://www.pse.com.ph/stockMarket/listedCo mpanyDirectory.html . Retrieved May 15, 2019

https://www.set.or.th/set/commonslookup.do?| anguage $=$ en $\&$ country $=U S \&$ prefix $=A$. Retrieved May 15, 2019

https://www2.sgx.com/securities/stockscreener. Retrieved May 15, 2019

Newey, W., \& McFadden, D. (1994). Large sample estimation and hypothesis testing, Handbook of Econometrics.

Nguyen, D. K., \& Bellalah, M. (2008). Stock market liberalization, structural breaks and dynamic changes in emerging market volatility. Review of Accounting Finance, 7(4), 396-411. https://doi.org/10.1108/147577008109207 84

Pamungkas, B. C., \& Darmawan, A. (2016). Pengaruh Nilai Tukar USD DAN Bursa ASEAN Terhadap Indeks Harga Saham Gabungan ( IHSG ) ( Studi pada Bursa Efek Indonesia Periode 2014 - 2016 ). Jurnal Administrasi Bisnis (JAB), 60(1), 1-9.

Rath, M. J. and B. N. (2017). The dynamic linkage between exchange rate, stock price and interest rate in India. Studies in 
Economic Finance, 34(3), 383-406. https://doi.org/10.1108/SEF-02-20160043

Robiyanto, R. (2017). The Analysis Of Capital Market Integaryion In ASEAN Region By Using The OGARCH Approach. Jurnal Keuangan Dan Perbankan, 21(040), 169175.

Robiyanto, R. (2018a). The Dynamic Correlation between ASEAN-5 Stock Markets and World Oil Prices. Jurnal Keuangan Dan Perbankan, 22(2), 198210.

Robiyanto, R. (2018b). the Effect of Gold Price Changes, Usd/ldr Exchange Rate Changes and Bank Indonesia (Bi) Rate on Jakarta Composite Index (Jci)'S Return and Jakarta Islamic Index (Jii)'S Return. Jurnal Manajemen Dan Kewirausahaan, 20(1), 45. https://doi.org/10.9744/jmk.20.1.45-52

Robiyanto, Sugeng, W., Pangestuti, \& Demi, I. R. (2017). Testing Commodities As Save Haven And Hedging Instrument On Asean's Five Stock Markets Robiyanto*. Jurnal Ekonomi Kuantitatif Terapan, 10(2), 231-238.

Yusniar, M. W., \& Sufi Jikrillah. (2018). Reaksi Pasar Modal dan Pasar Uang Dunia Terhadap Pemilihan Presiden Amerika Serikat 2016. Jurnal Inovasi Bisnis Dan Manajemen Indonesia, 1(September), 510-521.

Zivkov, D. (2016). Dynamic Correlacion Between Stock Returns And Exchange Rate And Its Dependence On The Conditional Volatilities. Bulletin of Economic Research, 68(2005), 28-41. https://doi.org/10.1111/boer.12059 